\title{
加工音を用いたYAGレーザー加工溝深さ変化のモニタリング
}

\author{
栗田 恒雄, 大野 幸彦*, 仲井 強** \\ 工業技術院機械技術研究所（テ305-8564 茨城県つくば市並木 1-2) \\ *東京都立科学技術大学工学部機械システム工学科（テ191-0065 東京都日野市旭が丘6-6) \\ **東京都立科学技術大学大学院（テ191-0065 東京都日野市旭が丘6-6）
}

\section{A Study of Groove Depth Profile Monitoring Using the YAG Laser Processing Sound}

\author{
Tsuneo KURITA, Tomohiko ONO,* and Tsuyoshi NAKAI** \\ Mechanical Engineering Laboratory, 1-2 Namiki, Tukuba, Ibaraki 305-8564 \\ *Department of Mechanical Systems Engineering, Faculty of Engineering, Tokyo Metropolitan Institute of Technology \\ 6-6 Asahigaoka, Hino, Tokyo 191-0065 \\ **Master grade school, Tokyo Metropolitan Institute of Technology, 6-6 Asahigaoka, Hino, Tokyo 191-0065
}

(Received May 6, 1999)

\begin{abstract}
The final goal of this research is to construct a laser processing system to manufacture stepped shapes by utilizing detected processing sound. In order to achieve this goal, the basic investigations concern analyzing the relationship between laser processing characteristics and processing sound. The main purpose of this report is verify experimentally the possibility of monitoring the processed depth profile by using the value and fluctuation of the sound pressure level of processing sound. The main findings of this research are as follows: (1) The relationship between the depth of groove and sound pressure level can be represented by linear equation when $\mathrm{Al}_{2} \mathrm{O}_{3}+\mathrm{TiC}$ ceramic is used as the work material. (2) There exists a linear relationship between both fluctuations of bottom roughness of processed groove and sound pressure level when the laser energy per pulse is kept constant. (3) The depth profile of processed groove can be monitored by using processed sound.
\end{abstract}

Key Words: YAG laser, Laser grooving, Processing sound, Acoustic monitoring, Ceramic material

\section{1. 緒 論}

セラミックなどの硬質材料は硬度が高い特徵に加えて, 熱伝導率が高い, 比重が小さい等の理由から, 先端材料と して様々な分野の製品に応用されている1)。しかし, 高硬 度, 高脆性等の理由により, 製品として必要な形状に精度 よく加工することが困難である。レーザー加工は非接触 加工であるために被加工材料の機械的特性に影響を受け ず加工することが可能で, セラミックなどの硬質材料を加 工するのに有効であると考えられるが, 物理的接触によっ て加工を行わない, 加工時に加熱, 溶融, 蒸発等のプロセス が連続して発生する等の理由により加工状態を把握する ことが非常に難しい. 従って,レーザー加工時に発生する 様々な出力から加工状態, 加工品位などを監視するレー ザー加工システムを開発することは非常に有効であると 考えられる。このようなシステムを構築するために, レー ザー加工時に発生するプラズマ2), レーザー加工時におけ る被加工材料の温度 ${ }^{3)}$, 被加工材料の振動 ${ }^{4,5)}$, アシストガス 吹き付け時の反響音6,7)等のようなレーザー加工時に発生 する出力を利用し加工状態を把握する試みが行われてい る ${ }^{8,9)}$. 本研究の最終目標は, レーザー加工時に発生する 様々な出力のうち, 加工時に発生する音響を用いて加工状
態を把握, 制御するレーザー加工システムを開発すること である。その最終目標の前段階としてステップ形状を創 成することを対象としたレーザー溝加工に扔いて, 加工時 に発生する加工音を用いることにより加工状態を把握す ることを考え, 本報では加工状態の把握に必要な溝加工時 に発生する加工音と溝深さ, 抢よび音圧レベル変化量と加 工溝深さのゆらぎ振幅との関係を実験的に求めること, ま たその関係を用いて加工時に発生した加工音をもとに加 工溝の縦断面形状をモニタリングすることを目的として 研究を行った.

\section{2. 実験機器および実験方法}

\section{1 実験機器}

Fig.1にレーザー加工時に発生する加工音を検出および 分析するために用いた実験機器の構成を示す。レーザー 加工機は連続励起の $\mathrm{TEM}_{00}$ シングルモードYAGレーザー にAO-Qスイッチを付加したものを用いた．加工音と加工 特性の関係を示すために溝加工を行い, 発生した加工音を レーザー光照射点から $40 \mathrm{~mm}$, 被加工材料の表面に対して $30^{\circ}$ の位置に設定したコンデンサマイクロフォンで集音し てからFFT解析装置に収録した。収録した加工音より周波 


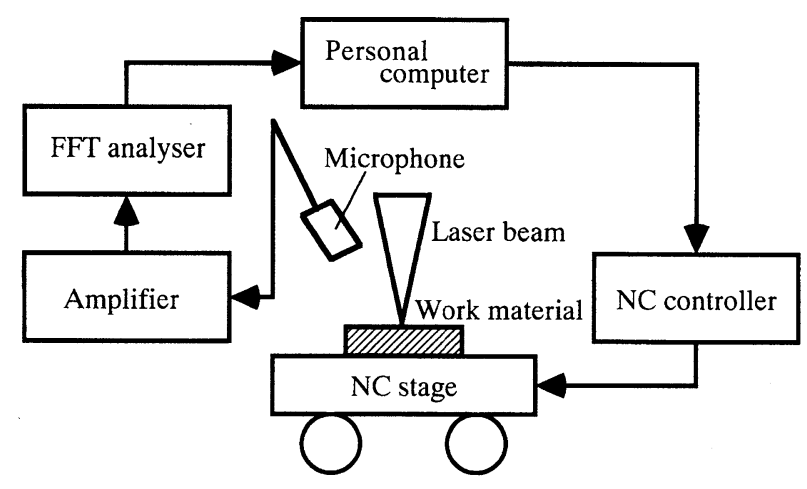

Fig.1 Experimental setup for a detection and an analysis of a laser processing sound.

数特性を求め, 特定周波数における音圧レベルの時間変化 を求めた。一方, 溝加工した被加工材料を, 溝方向に対し て,溝の最も深い底面が現れるまでダイヤモンド砥石を用 いて研削し, 加工溝の縦断面形状を求めた。 研削によって 現れた縦断面形状を走査型電子顕微鏡によって撮影し,加 工されている部分を観察した。

\section{2 実験方法}

筆者らは, レーザー溝加工において発生した加工音と加 工特性との相関性を実験的に求めている10,11). しかし, 溝 深さ, 溝断面積などの加工特性は加工した溝の横断面形状 を数ヶ所計測し,それらの值を平均することによって算出 している。また加工音も溝加工開始時から終了時までの全 域について収録した音を分析している。このため加工音と 加工特性の関係は各々平均化された状態におけるデー夕を 基にして求めたものであり, 溝加工中に発生する加工音の ゆらぎと加工特性との相関性を考察する場合, 従来の相関 性を適用することは難しい. 従って本研究では溝の長さが $1.25 \mathrm{~mm}$ であるレーザー溝加工をおこない, 加工中に発生し た加工音と溝の縦断面形状を比較し, 両者の相関性を実験 的に求めた. またこの相関性が, 加工条件の変化によって どのように変化するかを明らかにした。 なお,前報におい てレーザーパルスを照射したときに発生した音圧の最大振 幅である加工音の強さと, 溝の横断面形状における1パルス あたりの除去溝断面積との間に相関関係が存在することを 実験的に示しているが11), 加工のモニタリングを目的とし た本研究では, レーザー加工機の駆動音等加工以外の雑音 を排除すること,加工音圧の最大振幅をFFT解析装置によっ て自動的に抽出することが難しいなどの理由より,加工音 として特定周波数における音圧レベルを考え, 特定周波数 における音圧レベルの時間変化を測定した。

次に,これらの結果が加工音を用いた加工状態のモニ夕 リングに有効であるかどうか知るために, レーザー加工機 の加工条件をレーザーエネルギー $0.62 \mathrm{~mJ} / \mathrm{pulse}, \mathrm{Q}$ スイッチ 周波数 $1 \mathrm{kHz}$ と一定で, ステージ移動速度のみを变化させる ことによって $\mathrm{Al}_{2} \mathrm{O}_{3}+\mathrm{TiC}$ 設定した形状に加工し, 発生し た加工音から溝の縦断面形状のモニタリングをおこなっ た.このモニタリング結果と, 実際に加工された溝の縦断 面形状を比較した。

\section{3. 実験結果および考察}

\section{1 加工音と加工特性の関係}

\subsection{1 加工音と溝の縦断面形状の関係}

レーザー溝加工中に発生する加工音とそのとき形成さ れた溝の縦断面形状との関係を知るために, レーザー加工 条件をレーザーエネルギー $0.25 \mathrm{~mJ} / \mathrm{pulse}$, ステージ移動速度 $0.1 \mathrm{~mm} / \mathrm{s}, \mathrm{Q}$ スイッチ周波数 $1 \mathrm{kHz}$ としたときの加工音の周波 数特性において, 特定周波数 $10 \mathrm{kHz}$ における音圧レベル成 分の時間変化とそのときに加工された溝の縦断面形状を 求めFig.2に示す. Fig.2において溝の縦断面形状は, 上部が 加工された溝底面側, 下部は被加工材料の表面側を示して いる. また,加工された縦断面形状の変化をわかりやすく 示すために溝底部周辺のみを, 縦方向に拡大して表示し, 加 工時間と特定周波数における音圧レベル, 加工時間と加工 溝をそれぞれ対応させた。この図より, 特定周波数におけ る音圧レベルの時間変化と加工された溝の縦断面形状に おける溝底部の変化を比較すると, 両者の変化は非常に類 似していることが確認できる。

さらに両者に定量的な関係が存在するかどうかを調べ るため, 同図の加工開始点からある時間経過した何点かに おける溝深さと音圧レベルの值を測定し, 両者の関係を表 した結果をFig.3 (a)におけるステージ移動速度 $0.1 \mathrm{~mm} / \mathrm{s}$ の 直線として示す。この結果から, 加工された溝深さと, そ の時に発生した加工音に含まれる特定周波数における音 圧レベルの值は強い相関関係が存在することが理解でき る.

次に上記の関係が加工条件および被加工材料を変化さ せた場合においても成り立つかどうかを確認するために, 同様の実験と測定を行った. Fig.3 (a)に, ステージ移動速 度を更に 0.05 おび $0.15 \mathrm{~mm} / \mathrm{s} の 2$ 段階追加して実験した結 果を示す. 同図より特定周波数の音圧レベルと溝深さの 間には, ステージ移動速度を $0.05 \sim 0.15 \mathrm{~mm} / \mathrm{s}$ の範囲で変化 させた場合にも直線関係が存在することが確認できた。 またこれらのステージ移動速度の場合に, 溝深さが10 $\mu \mathrm{m}$ 変 化すると特定周波数における音圧レベルが約 $5 \mathrm{~dB}$ 変化して おり，すべての直線の勾配は等しいことが明らかとなっ

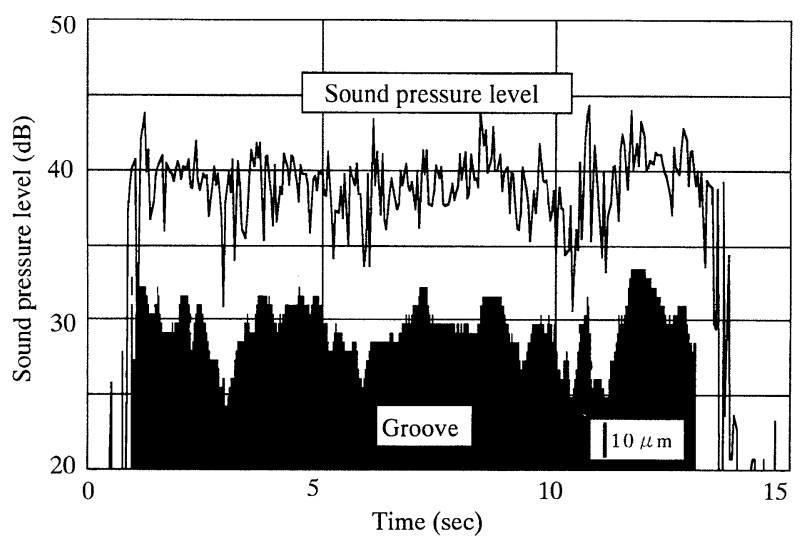

Fig.2 Fluctuations of sound pressure level and bottom of groove versus processing time. Laser energy: 0.25 $\mathrm{mJ} / \mathrm{s}$, stage travel speed: $0.1 \mathrm{~mm} / \mathrm{s}$, Q-sw. frequency: $1 \mathrm{kHz}$, and work material: $\mathrm{Al}_{2} \mathrm{O}_{3}+\mathrm{TiC}$. 


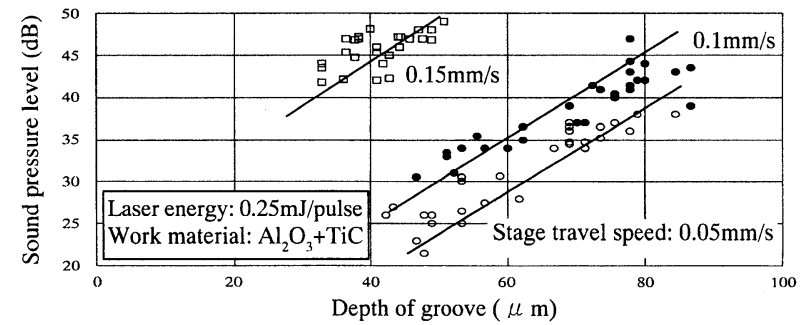

(a)

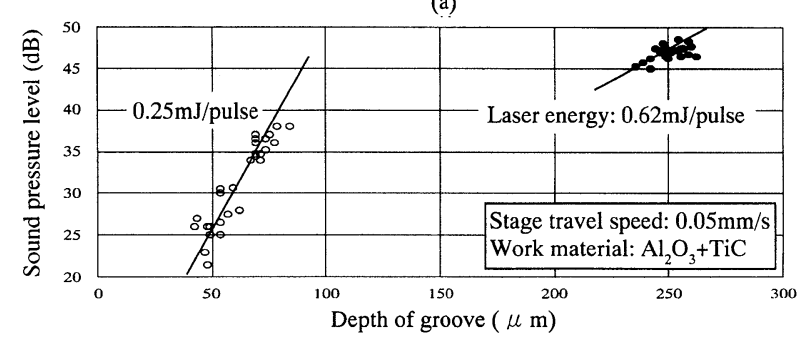

(b)

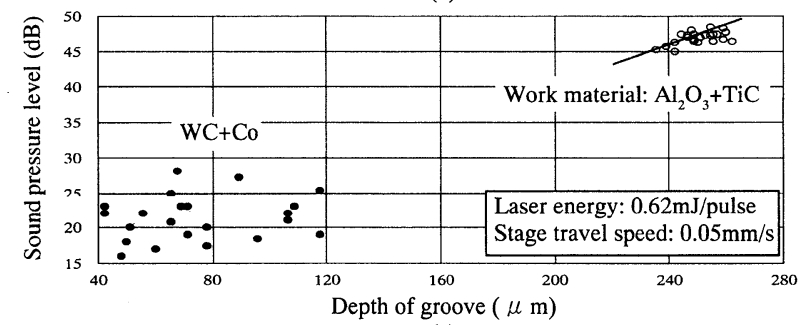

(c)

Fig.3 Relationship between depth of groove and sound pressure level. Q-sw. frequency: $1 \mathrm{kHz}$.

た。一方, Qスイッチ周波数 $1 \mathrm{kHz}$, ステージ移動速度を

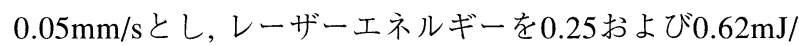
pulseに変化させた場合の両者の関係を同図 (b)に示す。こ の図より供給したエネルギーを変えた場合にも音圧レベ ルと溝深さの間には直線関係が存在するが, 両者の直線の 勾配は大きく異なっていることが理解できる。つぎに, 特 定周波数における音圧レベルと溝深さの相関性におよぼ す被加工材料の影響を調べるために, 被加工材料 $\mathrm{Al}_{2} \mathrm{O}_{3}+$ $\mathrm{TiC}$ およびWC + Coで求めた結果を同図 (c)に示す．被加工 材料がWC + Coの場合には $\mathrm{Al}_{2} \mathrm{O}_{3}+\mathrm{TiC}$ 場合とは異なり, 音圧レベルと溝深さの間には相関性が存在しないことが 見いだされた。

\section{1 .2 音圧レベル変化量と加工溝深さのゆらぎ振幅 の関係}

前章においてレーザー溝加工時に発生した加工音の特 定周波数における音圧レベルとそのとき加工された溝深

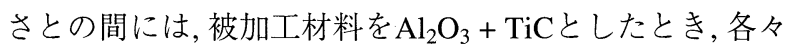
の加工条件において定量的な相関関係が存在することを 示した.このことは, 加工中に発生した特定周波数におけ る音圧レベルとそのとき加工された加工溝の溝深さは1対 1に対応していることを示している. しかし,加工条件の変 化に対してこの直線的な関係は種々変化する。一方実際 のレーザー加工では, 種々のレーザー加工条件を広い範囲 で変化させることが考えられる：そのため,レーザー加工 の状態を監視するには, 加工特性と加工音との相関性が加 工条件の変化することによってどのように変化するかを
系統的に調査することが重要である.

従って本章では, レーザー溝加工時に発生した加工音の 周波数特性における特定周波数の音圧レベルの変化とそ のとき加工された溝の縦断面形状における溝深さのゆら ぎに注目し, 加工条件の変化に対する両者の関係を実験的 に示した。

Fig.4はレーザーエネルギーを $0.25 \sim 0.62 \mathrm{~mJ} / \mathrm{pulse}$ 範囲 で変化させ，それぞれのレーザーエネルギーにおいてス テージ移動速度を $0.02 \sim 0.15 \mathrm{~mm} / \mathrm{s}$ の範囲で変化させた音圧 レベル変化量と加工溝深さのゆらぎ振幅の関係である. なお, 音圧レベル変化量は, それぞれの加工条件において 加工をおこなう際発生した加工音をFFT変換して周波数成 分10kHzにおける音圧レベル值の時間に対する変化を求め, その結果から音圧レベルの高い順から3番目,低い順から3 番目を選びそれらの差とした。また, 加工溝深さのゆらぎ 振幅は, それぞれの加工条件における溝の縦断面形状を求 め, 溝深さの変化から十点平均粗さ $\left(R_{\mathrm{Z}}\right)$ を読みとり, その 值とした。 まず, 加工溝深さのゆらぎ振幅と音圧レベル変 化量との関係を示す. 被加工材料は $\mathrm{Al}_{2} \mathrm{O}_{3}+\mathrm{TiC}$ 、 、ステー ジ移動速度およびQスイッチ周波数を何段階かに変化させ た。同図はレーザーエネルギーをパラメータとして示し ているが,この值が一定であれば加工条件に依存せずに加 工溝深さのゆらぎ振幅と音圧レベル変化量との関係は直 線で表すことができ,その勾配は供給するレーザーエネル ギー量に依存していることが理解できる，同図に一般性 を与えるために, これら直線の勾配とレーザーエネルギー の関係を示したのがFig.5である。なお, ステージ移動速度 を変化させたときの加工溝深さのゆらぎ振幅と音圧レべ ル変化量の直線の勾配は各加工条件における点が比例関 係にあると仮定して, 最小 2 乗法によって比例定数を求め た。これより,レーザーエネルギーの逆数と Fig.4の各直線 の勾配の值の間には直線関係があることが見いだされ た.このことは加工溝深さのゆらぎ振幅と音圧レベル変 化量との間に存在する直線関係における傾きが, 供給する レーザーエネルギーを $0.25 \sim 0.62 \mathrm{~mJ} / \mathrm{pulse}$ 範囲で変化さ せる限り,レーザーエネルギー量の逆数に対応して直線的

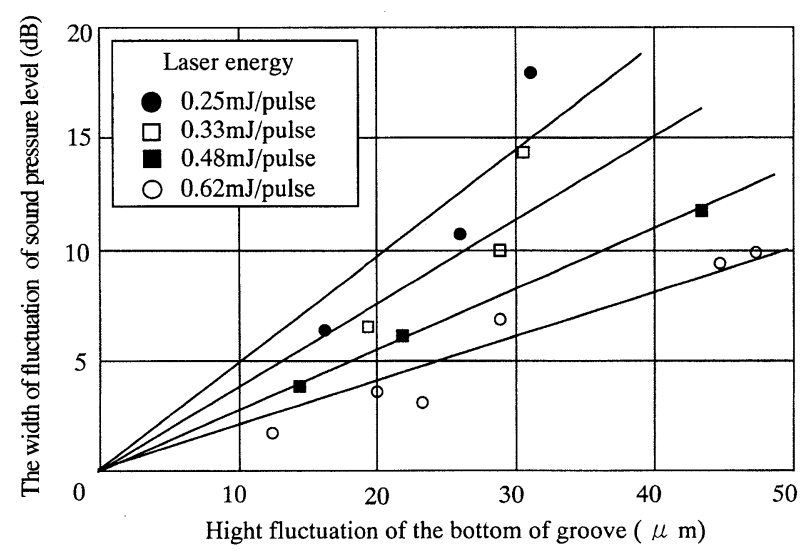

Fig.4 Relationship between the hight fluctuation of bottom of groove and the width of fluctuation of sound pressure level. Stage travel speed: $0.05 \sim 0.15 \mathrm{~mm} / \mathrm{s}$, Q-sw. frequency: $1 \sim 5 \mathrm{kHz}$, and work material: $\mathrm{Al}_{2} \mathrm{O}_{3}$ $+\mathrm{TiC}$. 


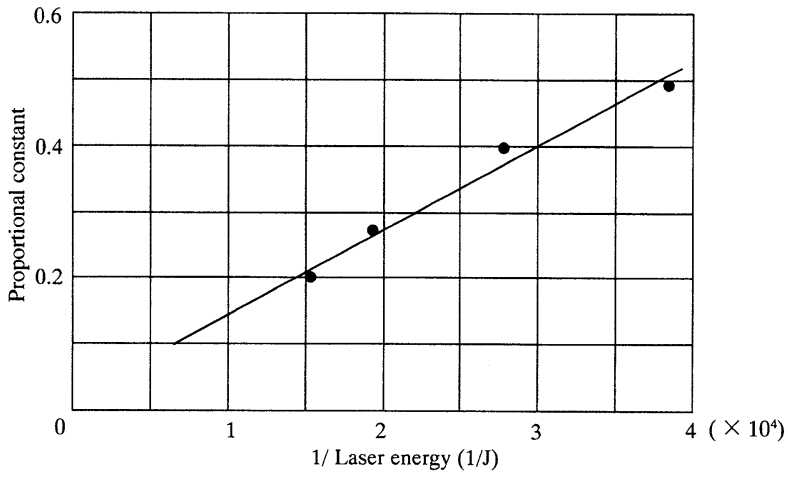

Fig.5 Relationship between inverse value of laser energy and proportional constant.

に変化することを示している。

\section{2 溝の縦断面形状モニタリング}

本研究の最終目標はレーザー加工時に発生する音響を 用いて加工状態を制御するレーザー加工システムを開発 することである．前章において実験的に求めた関係が本 研究の最終目標を達成するために有効かどうか確認する ために, “3.1 加工音と加工特性の関係”における実験結果 を用いて溝の縦断面形状をモニタリングすることを試み， 加工実験を行った。

Fig.6に溝の縦断面形状をモニタリングする概念図を示 す。これは希望の縦断面形状をレーザーエネルギー $0.62 \mathrm{~mJ} /$ pulse, Qスイッチ周波数 $1 \mathrm{kHz}$, 被加工材料 $\mathrm{Al}_{2} \mathrm{O}_{3}+$ $\mathrm{TiC}$ の一定条件においてステージ移動速度を $0 \sim 1.5 \mathrm{~mm} / \mathrm{s}$ の 範囲で変化させることにより加工し, その際発生した加工

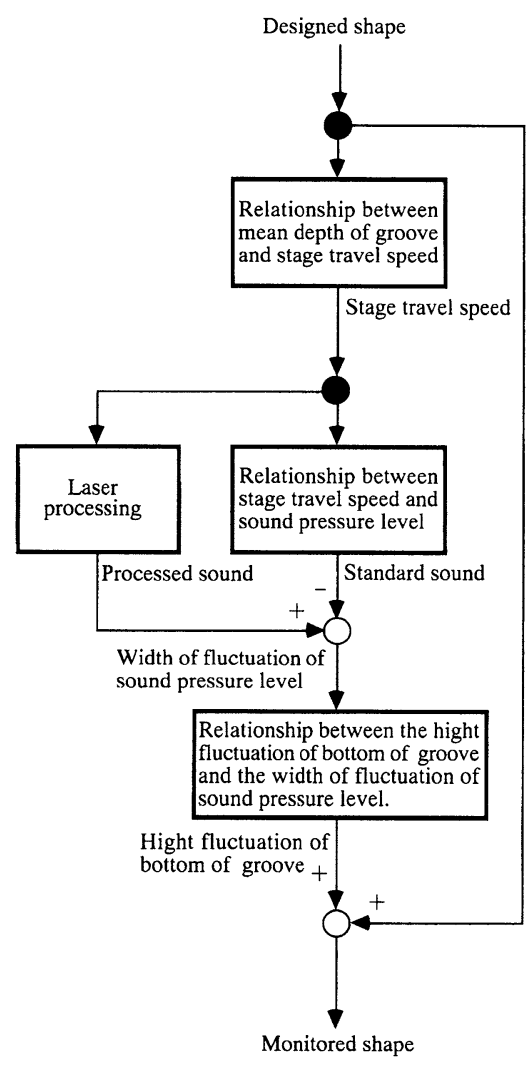

Fig.6 Structure of monitoring system.
音から加工特性と加工音に関する実験デー夕を用いて溝 の縦断面形状をモニタリングするものである，溝の縦断 面形状をモニタリングするために, 4つの要素を用いた。

(1) 平均溝深さとステージ移動速度の関係

Fig.7に平均溝深さとステージ移動速度の関係を示す. 平均溝深さは, 溝深さを溝の進行方向に対して垂直に切断 した断面において被加工材料表面から最も深い部分の距 離とし, 溝深さの值を4回求めそれらの平均值とした。この 図より平均溝深さを入力すると, 溝深さとステージ移動速 度の関係を用いて, その平均溝深さを加工するのに必要な ステージ移動速度が導き出せる。なお, Fig.7の関係を求め た実験条件において, 横断面形状の溝幅はステージ移動速 度を変化させても変化しない.

(2) ステージ移動速度と平均音圧レベルの関係

Fig.8にステージ移動速度と平均音厈.レベルの関係を示 す10). 平均音圧レベルは, 溝加工中に発生した加工音を FFT解析装置により解析し, 周波数成分 $10 \mathrm{kHz}$ における音圧 レベルの時間変化曲線から求めた平均值とした。この図 より, あるステージ移動速度を代入すると, そのステージ 移動速度で溝加工を行ったとき発生する加工音の平均音 圧レベルを示す基準加工音が導き出せる.

(3) 加工

実際に加工を行うことを示しておりステージ移動速度 を代入すると, 代入したステージ移動速度で加工を行い, 加 工された溝の縦断面形状を示す実加工形状, 加工中に発生 した加工音における特定周波数の音圧レベルと定義する 実加工音が出力されると考えた.

(4) 音圧レベル変化量と加工溝深さのゆらぎ振幅の関係

Fig.4において求めた関係である。このシステムの場合, ステージ移動速度のみ変化させているので, レーザーエネ ルギーは一定である. “3.1.2 音圧レベル変化量と加工溝深 さのゆらぎ振幅の関係”においてレーザーエネルギーが一 定の場合, 音圧レベル変化量と, 加工溝深さのゆらぎ振幅の 関係は, 直線で表現できることが明らかになっている。こ こでは, 加工条件からレーザーエネルギーが $0.62 \mathrm{~mJ} / \mathrm{pulse}$ あることが分かっているので, Fig.4においてレーザーエネ ルギー0.62mJ/pulseにおける直線関係を用いた。ただし, 音 圧レベル変化量が負の值で代入された場合はFig.4の関係に

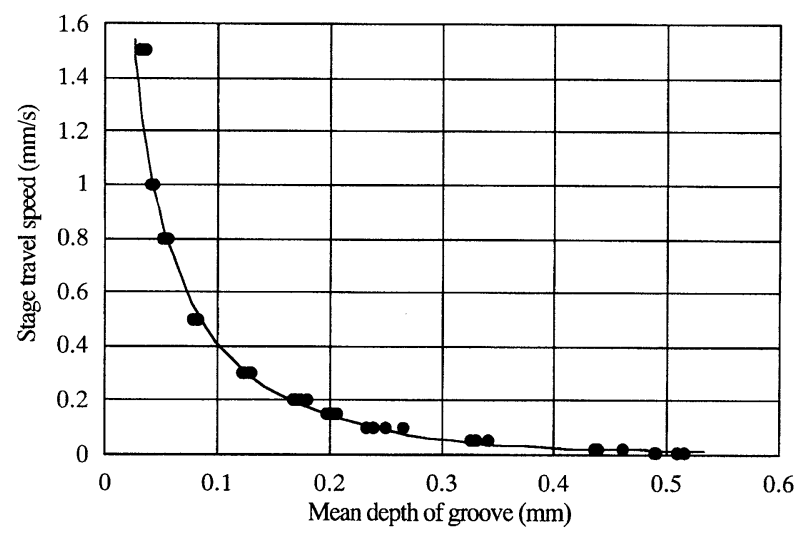

Fig.7 Relationship between mean depth of groove and stage travel speed. Laser energy: $0.62 \mathrm{~mJ} / \mathrm{pulse}, \mathrm{Q}-\mathrm{sw}$. frequency: $1 \mathrm{kHz}$, and work material: $\mathrm{Al}_{2} \mathrm{O}_{3}+\mathrm{TiC}$. 


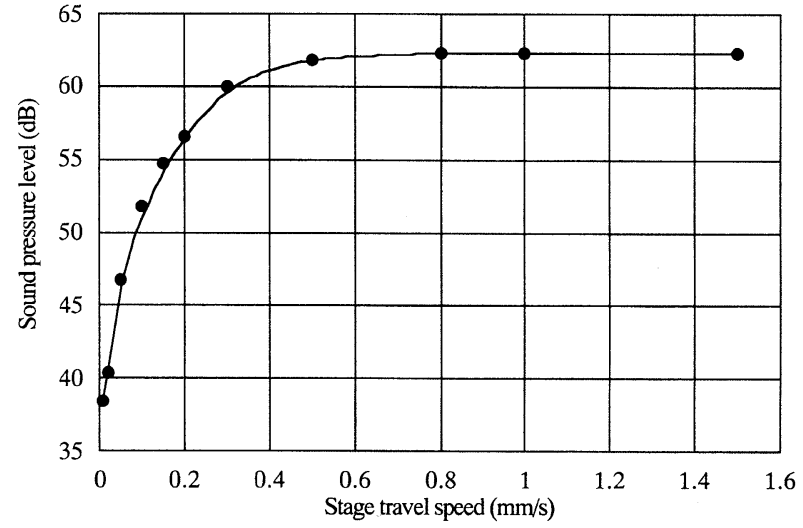

Fig.8 Relationship between stage travel speed and sound pressure level. Laser energy: $0.62 \mathrm{~mJ} /$ pulse, $\mathrm{Q}-\mathrm{sw}$. frequency: $1 \mathrm{kHz}$, and work material: $\mathrm{Al}_{2} \mathrm{O}_{3}+\mathrm{TiC}$.

直接音圧レベル変化量を代入することができないので, 加 工溝深さのゆらぎ振幅は音圧レベル変化量の絶対值を代入 した結果に負符号をつけた值で導き出すものとした。

次にFig.6をもとにモニタリング形状創製のためのプロ セスについて述べる. 加工したい溝の縦断面形状を表す 設計形状から読みとった溝深さの值を平均溝深さとし, 平 均溝深さとステージ移動速度の関係を用いて, 設計形状を 加工することができるステージ移動速度を算出する。そ のステージ移動速度に従いNCステージを制御して実際に 加工を行った。 またステージ移動速度は, ステージ移動速 度と平均音圧レベルの関係に代入して基準加工音を算出 した. ステージ移動速度と平均音圧レベルの関係, および 平均溝深さとステージ移動速度の関係における平均音圧レ ベル, 平均溝深さは溝加工中の平均值を求めているので, こ れらの值を通常加工が行われたときに発生する加工音, 加 工される溝深さと考えた．基準加工音と実際に加工を 行ったときの特定周波数における音圧レベル值の差を, 通 常発生する加工音と実際に発生した加工音の差と考え, こ の值を音圧レベル変化量とした．音圧レベル変化量を音 圧レベル変化量と加工溝深さのゆらぎ振幅の関係に代入 し出力された加工溝墚さのゆらぎ振幅は, 通常の加工で創 成できる加工溝深さと実際に加工された溝深さの差と考 えられる。また, “3.1.1加工音と溝の縦断面形状の関係”に おいて加工音の特定周波数における音圧レベルとそのと き加工された溝深さは 1 対 1 に対応することが明らかと なっているので, 加工溝深さのゆらぎ振幅と設計形状との 和をモニタリング形状と考えた。この結果と,加工された 溝の縦断面形状である実加工形状との比較を行った。

Fig.9は,溝の縦断面形状に2段のステップ形状を設定し た設計形状と，モニタリング形状および実加工形状の縦断 面形状を同時に示している。なお実加工形状は, 被加工材 料を研削して溝の縦断面形状を創成し,SEMで断面形状を 撮影して求めた。同図に示すようにこの研削作業時の誤 差が主要な原因で, 実加工形状はすべての加工位置におい てモニタリング形状よりも小さな值(溝が浅いことに対応 する)となるのであるが, モニタリング形状と加工形状の差 は $50 \mu \mathrm{m}$ 未満の值であって, ほぼ一致していると評価でき る. 従って被加工材料を $\mathrm{Al}_{2} \mathrm{O}_{3}+\mathrm{TiC} と し$, ステージ移動速

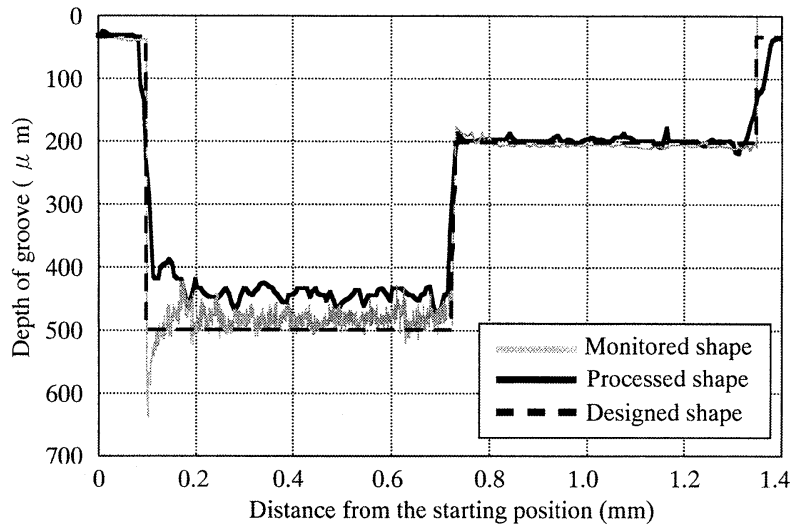

Fig.9 Depth profile of processed groove and monitored result. Laser energy: $0.62 \mathrm{~mJ} /$ pulse, $\mathrm{Q}-\mathrm{sw}$. frequency: $1 \mathrm{kHz}$, and work material: $\mathrm{Al}_{2} \mathrm{O}_{3}+\mathrm{TiC}$.

度のみを変化させたレーザー溝加工において, 加工音を検 出・解析すること,および事前に収集して解析した加工条 件と加工音および加工音と加工特性との相関性に関する データを用いることで, 縦断面形状をかなりの精度で検出 できることが証明できた。

\section{4. 結 論}

本研究で示した結論を以下に記述する.

1) YAGレーザー加工をおこなったときの溝深さとそのと き発生した加工音の特定周波数における音圧レベルと の関係を求め,両者の間には被加工材料を $\mathrm{Al}_{2} \mathrm{O}_{3}+\mathrm{TiC}$ と したとき定量的な関係が存在することを実験的に示し た. 一方, 被加工材料をWC + COとした場合, 相関は得 ることができなかった。

2) レーザーエネルギーの逆数とステージ移動速度を変化 させたときの加工溝深さのゆらぎ振幅と音圧レベル変 化量の直線の傾きとの間には, 比例関係が存在すること を明らかにした。

3）加工音を基に作成した溝の縦断面形状であるモニタリ ング形状と, 実際に加工を行いもとめた実加工形状の比 較をおこなった結果, 両者の形状はほぼ一致し, 本研究 で示したモニタリングの方法は有効であることを実験 的に示した。

\section{参考文献}

1) 今中 治：セラミックス加工ハンドブック(建設産業調査会, 1987) p.602.

2) P. Sheng and G. Chryssolouris: J. Mater. Technol. 43 (1994) 125.

3) P. Sheng and G. Chryssolouris: J. Mater. Technol. 43 (1994) 145.

4) D. Charalabos: Manufacturing Science and Engineering ASME. 2 (1995) 487.

5) J. Yang, T. Sanderson, G. Graham, and C. Ume: Manufacturing Science and Engineering ASME. 68 (1994) 245.

6) Hongping Gu and W. W. Duley: Appl. Phys. 29 (1996) 550.

7) Hongping Gu and W. W. Duley: Appl. Phys. 29 (1996) 556.

8) W. W. Duley and Y. L. Mao: Appl. Phys. 27 (1994) 1379.

9) K. S. Chawla and J. Norrish: COMPUTER TECHNOLOGY IN WELDING. 3 (1992) 54.

10）栗田 恒雄, 大野幸彦, 森田昇：レーザー研究 25 (1997) 88 .

11) 栗田恒雄, 大野幸彦, 森田昇：レーザー研究 27 (1999) 286. 